\title{
Implementing inclusive education
}

Dr Matthew J. Schuelka

University of Birmingham

29 August 2018

\section{Question}

What are the key elements of successful implementation of inclusive education? How is 'successful inclusive education' defined in the literature? How do we know that inclusive education is 'successful'? What factors have been identified in the literature that both enable and challenge the successful implementation of inclusive education in low-resource and low-income countries? What are the key strategies related to the successful implementation of inclusive education?

\section{Contents}

1. Summary

2. What is 'successful inclusion'?

3. How do we know that inclusive education is successful?

4. Challenges for inclusive education in low-income countries

5. Successful implementation strategies

6. References

The K4D helpdesk service provides brief summaries of current research, evidence, and lessons learned. Helpdesk reports are not rigorous or systematic reviews; they are intended to provide an introduction to the most important evidence related to a research question. They draw on a rapid desk-based review of published literature and consultation with subject specialists. 


\section{Summary}

The key elements of successful inclusive education implementation are:

- A clear concept and definition of inclusive education;

- Concrete inclusive education targets, indicators, measures, and outcomes;

- An understanding of existing structural, educational, and cultural challenges to successful implement;

- A well-designed implementation strategy that includes a clear plan, evaluation, and school review process;

- Providing inclusive education training, sustained support, and resources for all teachers and school leaders; and

- National leadership on inclusive education policy, education management information systems, curricular-reform, and coordinating social systems such as inclusive education and inclusive employment.

Successful inclusive education requires school transformation and systems change. However, much of this reform is design-focused, and not resource-intensive. It is important to emphasise that inclusive education means that all children are together in mainstream classrooms for the majority of their day. This has demonstrated positive effects on student achievement and social wellbeing - for all children - and is far more efficient and effective than special schools and special classrooms. Often, the term 'inclusive education' becomes synonymous with education for children with disabilities. Whilst this may still be the primary motivation for inclusive education, successful inclusive practice will be successful for all children with many different attributes such as ethnicity, language, gender, and socio-economic status.

Inclusive education is a continuous process of educational transformation, and a clear set of equity indicators - such as from UNESCO (2017) - can support inclusive education implementation. Measuring the success of inclusive education should go beyond merely counting students to evaluate access, but should include measures of educational quality, outcomes, and experiences. Understanding and evaluating teaching practices is also critically important. The Index for Inclusion toolkit, Supporting Effective Teaching project, and the Lao Inclusive Education Project by Save the Children (Grimes, 2010) are particularly useful inclusive education assessment tools, but other indicator sets and tools are also available.

The barriers to inclusive education are well-understood now, and include inadequacies in policy and legal support, resources and facilities, specialised staff, teacher training, pedagogical techniques, flexible curricula, supportive leadership, and cultural attitudes. However, current thinking suggests that it is perhaps more useful to think about ways in which existing successful inclusive education practices can be identified and scaled up, rather than focusing attention on deficiencies.

Key factors in inclusive education implementation include school and classroom level implementation such as school reviews and plans; training and supporting all teachers in inclusive practices, not just 'specialised' ones; and supporting school leadership to enact an inclusive vision for their schools. National-level implementation requires enabling policy to clearly articulate and support inclusive education; having strong systems to data collection and management; providing flexibility in curriculum; and coordinating with other aspects of society in which inclusive education factors, such as employment. 


\section{What is 'successful inclusion'?}

\section{Defining inclusive education and its importance}

Inclusive education has been defined in a myriad of different ways. Perhaps the most authoritative definitions come from United Nations agencies and from treaties such as the Convention on the Rights of Persons with Disabilities and the Incheon Declaration. According to the Committee on the Rights of Persons with Disabilities (UN 2016), inclusive education means:

- A fundamental right to education

- A principle that values students' wellbeing, dignity, autonomy, and contribution to society

- A continuing process to eliminate barriers to education and promote reform in the culture, policy, and practice in schools to include all students.

Additionally, and most importantly, inclusive education means that students with disabilities and other disadvantages are taught with their peers in a mainstream classroom for a majority of the school day. When most experts speak of 'inclusive education', this does not include special units or special classrooms (segregation), or placing children with disabilities in mainstream settings so long as they can adjust (integration). Inclusive education begins with the assumption that all children have a right to be in the same educational space (Cobley, 2018; Florian, Black-Hawkins \& Rouse, 2017; Hehir, et al., 2016; Schuelka \& Johnstone, 2012; UNESCO-IBE, 2016).

The importance of inclusive education is defined in its positive outcomes for all children - both with and without disabilities or other disadvantages. For example, The European Agency for Special Needs and Inclusive Education (EASNIE) (2018), has provided ample evidence that inclusive education increases social and academic opportunities for both children with and without disabilities, as well as significantly increases the likelihood that children with disabilities enrol in higher education and have better employment and life outcomes (see also Florian, Black-Hawkins \& Rouse, 2017; Hehir, et al., 2016).

\section{Defining 'success' in inclusive education}

Whilst there are various ways to define 'success' in inclusive education, the UNESCO (2017) Guide for Ensuring Inclusion and Equity in Education provides perhaps the clearest conceptualisation of how inclusive education can be deemed successful:

Table 1: Key dimensions for establishing inclusive and equitable education systems

1.1 Inclusion and equity are overarching principles that guide all education policies, plans, and practices

(2) 1.2 The national curriculum and its associated assessment systems are designed to respond effectively to all learners

1.3 All partners who work with learners and their families understand and support the national policy goals for promoting inclusion and equity in education

1.4 Systems are in place to monitor the presence, participation, and achievement of all learners within the education system 


\begin{tabular}{|c|c|}
\hline \multirow{4}{*}{  } & $\begin{array}{l}2.1 \text { The important national education policy documents strongly emphasize inclusion and } \\
\text { equity }\end{array}$ \\
\hline & $\begin{array}{l}2.2 \text { Senior staff at the national, district, and school levels provide leadership on inclusion and } \\
\text { equity in education }\end{array}$ \\
\hline & $\begin{array}{l}2.3 \text { Leaders at all levels articulate consistent policy goals to develop inclusion and equitable } \\
\text { educational practices }\end{array}$ \\
\hline & $\begin{array}{l}2.4 \text { Leaders at all levels challenges non-inclusive, discriminatory and inequitable educational } \\
\text { practices }\end{array}$ \\
\hline \multirow{4}{*}{  } & 3.1 There is high-quality support for vulnerable learners \\
\hline & $\begin{array}{l}\text { 3.2 All services and institutions involved with learners and their families work together in } \\
\text { coordinating inclusive and equitable educational policies and practices }\end{array}$ \\
\hline & $\begin{array}{l}\text { 3.3 Resources, both human and financial, are distributed in ways that benefit potentially } \\
\text { vulnerable learners }\end{array}$ \\
\hline & $\begin{array}{l}\text { 3.4 There is a clear role for special provision, such as special schools and units, in promoting } \\
\text { inclusion and equity in education }\end{array}$ \\
\hline \multirow{4}{*}{ 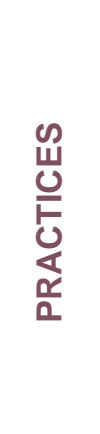 } & $\begin{array}{l}\text { 4.1 Schools and other learning centres have strategies for encouraging the presence, } \\
\text { participation, and achievement of all learners from their local community }\end{array}$ \\
\hline & $\begin{array}{l}\text { 4.2 Schools and other learning centres provide support for learners who are at risk of } \\
\text { underachievement, marginalization, and exclusion }\end{array}$ \\
\hline & $\begin{array}{l}\text { 4.3 Teachers and support staff are prepared to respond to learner diversity during their initial } \\
\text { training }\end{array}$ \\
\hline & $\begin{array}{l}\text { 4.4. Teachers and support staff have opportunities to take part in continuing professional } \\
\text { development regarding inclusive and equitable practices }\end{array}$ \\
\hline
\end{tabular}

Source: UNESCO (2017, pp. 17-36)

Most accepted definitions of inclusive education deem it as a continuous process, and so it should not be thought of as something to be achieved. Rather, the points above can be thought of as criteria for continuous evaluation and critical examination of education systems. In a substantive study of inclusive education in rural Canada, very similar attributes were identified as being crucial to the success of inclusive education (Timmons \& Thompson, 2017).

\section{How do we know that inclusive education is successful?}

The table in Section 2 above can be more succinctly summarised into five main components of successful inclusive education implementation:

1. inclusive polices that promote high outcomes for all students;

2. flexible and accommodative curriculum;

3. strong and supportive school leadership;

4. equitable distribution of resources; and

5. teachers who are trained in inclusive pedagogy and view it as their role to teach all learners in a diverse classroom. 


\section{Measuring and evidencing inclusive education}

One of the fundamental ways in which we have historically understood inclusive education 'success' is through quantitative tools that measure access. It is straightforward, though simplistic, to simply 'count' the number of children with disabilities in schools and classrooms as an inclusive education outcome. However, in the last decade or so there have been more innovative tools developed to capture not just access to education, but also the quality of education, educational outcomes, and experiences of inclusion for children with disabilities. In short, the current thinking is to move beyond measuring and accounting for simply just barriers to access, and offer more of a systems thinking approach (i.e. Carrington, et al., 2017; EASNIE, 2017; Sailor, 2015; Shogren, et al., 2015; Schuelka \& Johnstone, 2012).

Well-known measurement tools, such as the Index for Inclusion (Booth \& Ainscow, 2011), offer both a set of evaluative tools as well a developmental application to facilitate increased inclusion in school systems. Loreman, Forlin, and Sharma (2014) suggest that evaluating successful inclusive education can be distinguished through Inputs, Processes, and Outcomes; as well as conceptualised from the national level (macro), to the district (meso) and to school level (micro).

Table 2: The Relationship between the Micro-Meso-Macro Levels and the Inputs-Processes-Outcomes Model

\begin{tabular}{|c|c|c|c|}
\hline & INPUTS & PROCESS & OUTPUTS \\
\hline \multirow{5}{*}{ 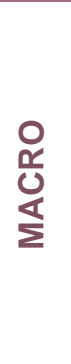 } & Policy & Climate & Participation \\
\hline & Staff PD \& teacher education & School practice & Student achievement \\
\hline & Resources and finances & $\begin{array}{l}\text { Collaboration and shared } \\
\text { responsibility }\end{array}$ & Post-school options \\
\hline & Leadership & Support to individuals & \\
\hline & & Role of special schools & \\
\hline \multirow{5}{*}{ 올 } & Policy & Climate & Participation \\
\hline & Staff PD \& teacher education & School practice & Student achievemen \\
\hline & Resources and finances & $\begin{array}{l}\text { Collaboration and shared } \\
\text { responsibility }\end{array}$ & Post-school options \\
\hline & Leadership & Support to individuals & \\
\hline & Curriculum & Role of special schools & \\
\hline \multirow{5}{*}{$\begin{array}{l}\text { O } \\
\stackrel{\mathbb{U}}{0} \\
\frac{1}{\Sigma}\end{array}$} & Resources and finances & Climate & Participation \\
\hline & Leadership & School practice & Student achievemen \\
\hline & Curriculum & Classroom practice & Post-school options \\
\hline & & $\begin{array}{l}\text { Collaboration and shared } \\
\text { responsibility }\end{array}$ & \\
\hline & & Support to individuals & \\
\hline
\end{tabular}

Source: Loreman, Forlin \& Sharma (2014, p. 169)

The measurement of each of the items in Table 2 above requires various collection methods and conceptualisations. Arguably the most important factor is education systems enabling inclusive 
education to take place structurally and culturally. However, teachers play a crucial role in the actual implementation of inclusive education, so understanding and evaluating teaching practices is of the utmost importance.

There have been many notable projects that have sought to identify and measure effective inclusive education practices by teachers. UNESCO-IBE (2016) have produced a thorough training toolkit for teachers, school leaders and policy-makers. Similar materials have come from agencies such as EASNIE (2011), the Commonwealth (Rieser, 2012), and Save the Children (2016; Save the Children \& EENET, 2018). The Supporting Effective Teaching [SET] longitudinal project (Jordan \& McGhie-Richmond, 2014) is a particularly excellent exemplar in identifying, measuring, and enhancing inclusive teaching practices. Through a rigorous Classroom Observation Scale, SET project members identified and evaluated effective classroom practices for inclusion, such as: classroom management, time management, lesson presentation, large group and whole-class instruction, small group and individual instruction, predominant teaching style, and classroom tone (for a much more detailed explanation, see the Appendix in Jordan \& McGhie-Richmond, 2014).

\section{Indicators of inclusive development: An example from Laos}

A particularly helpful example of developing indicators to measure the success of inclusive education can be found in Peter Grimes' longitudinal work in Laos for Save the Children (Grimes, 2010). Since the Lao Inclusive Education Project began in 1993, inclusive schools grew from 1 to 539 , and all student achievement measures - for children with or without disabilities - positively increased (Grimes, 2010).

Coming out of the initial project work, Grimes and other project staff developed 17 indicators to evaluate the current level of inclusive education in Laos:

1. All pupils feel welcome in the school

2. All students support each other in their learning

3. All students are well supported by school staff

4. Teachers and parents cooperate well

5. All students are treated equally as valued members of the school

6. All students feel that their opinions and views are valued
7. All students can access learning in all lessons

8. All students can access all parts of the school building

9. All students attend school every day

10. All students enjoy lessons

11. All students are engaged in all lesson activities

12. All students achieve their learning in all subjects according to their individual ability
13. All students learn together

14. All students have access to appropriate health services as necessary

15. School ensure that the all students enter the school

16. All vulnerable children are successful in their learning

17. School creates a school environment which supports all students' learning

The full list of clarifying questions related to each of the indicators above can be found in Appendix B in Grimes' (2010) Save the Children report. The data for these indicators were collected via a range of methods including questionnaires, interviews, reviews of school plans, community focus groups, and participatory discussion groups. During observations and evaluations by the project, a Quality Standard was implemented so that it was clear when successful inclusive education was observed (see Appendix A in Grimes, 2010). 


\section{Challenges for inclusive education in low-income countries}

The barriers to inclusive education are well understood, and expert consensus has not significantly changed since a few key and oft-cited papers in the early $21^{\text {st }}$ century set out the current understanding of the issues (i.e. Eleweke \& Rodda, 2002; Mittler, 2000; Peters, 2003). Because of this, many scholars are now advocating for inclusive education development to move beyond a deficit approach and to a focus on community collaboration, attention to existing assets, and scaling-up successful inclusive education policies and practices (Messiou, 2017; Phasha, Mahlo \& Dei, 2017; Schuelka \& Johnstone, 2012). As a large-scale example, the shift from barrier-deficit-thinking to enabling success and seeking 'what is working' in inclusive education can be seen in the World Bank and USAID partnership in Africa (World Bank, 2017). This follows a larger conceptual trend to view inclusive education not as a specialised approach for marginalised children, but one of overall educational systems transformation (Opertti, Walker \& Zhang, 2014)

Regardless of recent systemic conceptualisations of inclusive education and a focus on highlighting success, it is worth quickly reviewing the most significant obstacles and challenges to successful inclusive education implementation. The most commonly identified challenges to successful inclusion education implementation are:

- Lack of policy and legal support

- Inadequate school resources and facilities

- Inadequate specialised school staff

- Inadequate teacher training in inclusive thinking and techniques

- Didactic and passive pedagogical techniques

- Rigid curriculum that offers no accommodation, modification, or personalisation

- Unsupportive school and district leadership

- Socio-cultural attitudes about schools and disability

(e.g. Eide \& Ingstad, 2011; Eleweke \& Rodda, 2002; Johnstone \& Chapman, 2009; Mittler, 2000; Peters, 2003; Rose, 2010; Schuelka, 2018; Srivastava, de Boer \& Pijl, 2013; UNESCO, 2003)

\section{Successful implementation strategies}

One of the primary misunderstandings of inclusive education is a belief in the resource-intensity of such an endeavour. Many policy-makers immediately think of the costs of resources such as specialised teachers and equipment. However, study after study has evidenced the argument that inclusive education is actually cost-effective. It is far more efficient to have all children in one school and in mainstream classrooms, rather than in special classes and schools (ADB, 2010). The investment in inclusive education pays off significantly with increased participation in the economy by youths who have been given a high-quality education (Banks \& Pollack, 2013; UNICEF, 2015). In short, implementing inclusive education is not about increasing the educational budget; but about continuous, systemic, and sustained transformation of educational design, cultures, and values. 


\section{School and classroom level implementation strategies}

Ultimately, successful implementation of inclusive education occurs at the school and classroom level (Carrington, et al., 2017; Schuelka, 2018). There are three areas of implementation on which this report will focus: school structure and culture, teachers, and school leadership. These will be illustrated in a synthesis of the literature below into stages.

\section{Stage 1: Initial Review and Evaluation to Define Success}

All of the primary literature sources on implementing inclusive education (i.e. Booth \& Ainscow, 2011; Rieser, 2012; Swift Center, 2018; UNESCO-IBE, 2016) suggest that the first step in inclusive education implementation is to help schools understand their own challenges, assets, resources, value frameworks, stakeholders, and where to locate data and evidence. For example, the Index for Inclusion (Booth \& Ainscow, 2011) provides a Planning Framework to facilitate school evaluation for inclusion; likewise, the UNESCO-IBE (2016) resource pack provides a framework for school review. The SWIFT Center (2018) - a major development centre for inclusive school-wide transformation - has tools to facilitate school-level activities such as Design Planning, Resource Mapping, Data Practices, Forming Teams, and Setting Priorities. Sections 2 and 3 above also describe indicators for evaluating inclusive education success.

\section{Stage 2: Get Teachers Trained and On Board}

Teachers often feel that inclusive education is something they are told to do - often without support and resources - and it becomes a top-down burden rather than a collaborative process (Singal, 2009). Therefore, it is important for teachers to have the knowledge and skills to create inclusive classrooms, as well as for school leadership to provide an inclusive and innovative environment for teachers to flourish (more on this below). Traditionally, training in inclusive education techniques was offered as continuing professional development and one-off workshops. There is mounting evidence that these kinds of short-term, 'parachute' trainings do little in terms of impact and systemic change (Fullan, 2007; Kuroda, Kartika \& Kitamura, 2017; Rose \& Doveston, 2015). More sustainable inclusive education implementation would put more emphasis on inclusive pedagogy in pre-service teacher training for all teacher trainees, as well as sustained and continuous in-service development. This also positively affects teachers' attitudes towards inclusion by emphasizing that it is within their professional role to include all children in their classroom, and is not just the domain of specialists and special curriculum (Forlin \& Chambers, 2011; Graham \& Scott, 2016; Sharma, Simi \& Forlin, 2015; Subban \& Mahlo, 2017).

Teachers can also be motivated to be more inclusive by providing more structured and supported expectations as to how they teach and as to what inclusive education 'looks like' in the classroom. See Section 3 above for some ideas. UNESCO-IBE (2016, p. 109) suggests that there are eight indicators that can help teachers review their classrooms:

1. Teaching is planned with all students in mind

2. Lessons encourage the participation of all students

3. Students are actively involved in their own learning

4. Students are encouraged to support one another's learning

5. Support is provided when students experience difficulties

6. Classroom discipline is based on mutual respect and healthy living 
7. Students feel that they have somebody to speak to when they are worried or upset

8. Assessment contributes to the achievement of all students

Evidence from the literature strongly suggests that inclusive teaching practices raise the achievement of all children in the classroom (i.e. EASNIE, 2018; Sailor, 2015). In that way, inclusive teaching can be synonymous with quality teaching. Whilst many different definitions of quality teaching exist, there are some common toolkits such as The Foundations of Teaching (Save the Children \& EENET, 2018) and the UNESCO-IBE (2016) Resource Pack for Supporting Inclusive Education that can be helpful for all teachers. Good practices for inclusive and quality teaching include learner-centred pedagogy and universal design for learning.

\section{Stage 3: Leaders Should Demonstrate Positive Values}

School leadership is crucial for the successful implementation of inclusive education (Shogren, et al., 2015; Villa \& Thousand, 2016). Often the most inclusive and high-quality schools are those that have school leaders who lead with vision, inclusive values, motivation, autonomy, and trust in school staff (Schuelka, Sherab \& Nidup, 2018; Sherab, et al., 2015). A helpful set of indicators is provided by UNESCO-IBE (2016, p. 47) for school leaders to review their schools:

1. Everyone is made to feel welcome

2. Students are equally valued

3. There are high expectations for all students

4. Staff and students treat one another with respect

5. There is a partnership between staff and families

6. The school is accessible to all students

7. Senior staff support teachers in making sure that all students participate and learn

8. The school monitors the presence, participation, and achievement of all students

\section{Policy and national level implantation strategies}

It is important that national policy and guidance encourage and enable inclusive education practice at the school level. The first step is for national policy to clearly state that inclusive education is a right for all children. It is also important that inclusive education policies and guidance be made in collaboration and consultation with disabled persons organisations (DPOs), non-governmental organisations (NGOs), parents of children with disabilities, children with disabilities themselves, and other community stakeholders (Rieser, 2012). Unfortunately, all too often national inclusive education policy is aspirational, vague, and non-committal (Schuelka, 2017; Singal, 2006). Inclusive education policy needs to clearly articulate the values of inclusive education, as suggested in Section 2. Besides the appropriate legislation and collaboration with stakeholders, there are other strategies that countries can employ to aid in inclusive education implementation. These are briefly given below:

\section{Strengthen Education Management Information Systems (EMIS)}

Having detailed and up-to-date school and student information will support educational systems in understanding where and when children are not being fully included. In a recent UNICEF (2016a) study, many low-income countries were found to have inaccurate or missing data when it came to students with disabilities. Accurate data is important for finance and resource distribution, to identify barriers to inclusion and 'at risk' children, raise awareness of 
marginalisation, and facilitate communication between national and local levels. The UNICEF/Washington Group Child Functioning Module (UNICEF 2016b) is an example of a tool for collecting disability data that has been validated in a low-income and isolated country such as Fiji (Spunt, et al. 2017).

\section{Encourage curricular flexibility and strengthen learning outcomes}

A rigid, centralised curriculum without opportunity for modification or flexibility does not support inclusive education in schools (EASNIE, 2011; Nolet \& McLaughlin, 2005; Schuelka, 2018). Ministries of Education and other national educational policy groups have influence in regard to allowing curriculum to be modified, providing alternative forms of assessment, and allowing teachers and students to have ownership of the curriculum and learning outcomes. The literature strongly suggests that an increase in the diversity and breadth of learning outcomes, coupled with an increase in the variety of means that a student can achieve these learning outcomes, will facilitate successful implementation of inclusive education (EASNIE, 2017; Nelson, 2014;

Sæbønes, et al., 2015). Literature also suggests that learning personalisation for each individual student can be very successful (Carpenter, Ashdown \& Bovair, 2017; Rhim \& Lancet, 2018).

\section{Promote inclusive societies and economies}

One of the oldest conceptual and rights-based arguments for inclusive education is that inclusive schools will lead to inclusive societies (EASNIE, 2018). Whilst this may still be true, national governments can do more to support successful post-school outcomes such as inclusive employment and an accessible economy. Banks and Pollack (2013) make a convincing economic case that including all children in schools leads to significant national economic gains, provided that there is a continuum of inclusion that bridges the transition from school to postschool activities (higher education, vocational training, work). Inclusive education is only as successful as long as there are clear opportunities to benefit from learning and apply them to post-school outcomes (Hehir, et al., 2017; Heymann, Stein \& Moreno, 2014), and is especially important in rural and low-income countries (Umeasiegbu, Diallo \& Gere, 2014). 


\section{References}

ADB [Asian Development Bank] (2010). Strengthening inclusive education. Manila: ADB. Retrieved from: https://www.adb.org/publications/strengthening-inclusive-education

Banks, L.M. \& Polack, S. (2013). The economic costs of exclusion and gains of inclusion of people with disabilities: Evidence from low and middle income countries. London: CBM and the London School of Hygiene and Tropical Medicine.

Booth, T. \& Ainscow, M. (2011). The index for inclusion ( $3^{\text {rd }}$ ed.). Bristol: Centre for Studies on Inclusive Education.

Carrington, S., Pillay, H., Tones, M., Nickerson, J., Duke, J., Esibaea, B., Malefoasi A. \& Fa'asala, C.J. (2017). A case study of culturally informed disability-inclusive education policy development in the Solomon Islands. International Journal of Inclusive Education, 21(5), 495-506. DOI: 10.1080/13603116.2016.1218952

Carpenter, B., Ashdown, R. \& Bovair, K. (Eds.) (2017). Enabling access: Effective teaching and learning for pupils with learning difficulties $\left(2^{\text {nd }}\right.$ ed.). London: Routledge.

Cobley, D. (2018). Disability and international development: A guide for students and practitioners. London: Routledge.

EASNIE [European Agency for Special Needs and Inclusive Education] (2011). Key principles for promoting quality in inclusive education: Recommendations for practice. Odense, DK: EASNIE. Retrieved from: https://www.european-

agency.org/sites/default/files/key-principles-for-promoting-quality-in-inclusive-education-recommendations-for-practice_KeyPrinciples-2011-EN.pdf

EASNIE (2017). Raising the achievement of all learners in inclusive education: Lessons from European policy and practice. Odense, DK. Retrieved from: https://www.european-

agency.org/sites/default/files/ra_lessons_from_european_policy_and_practice-web_0.pdf

EASNIE (2018). Evidence of the link between inclusive education and social inclusion: A review of the literature. Odense, DK: EASNIE. Retrieved from: https://www.european-agency.org/sites/default/files/Evidence\%20\%20A\%20Review\%20of\%20the\%20Literature_0.pdf

Eide, A.H. \& Ingstad, B. (Eds.) (2011). Disability and poverty: A global challenge. Bristol: The Policy Press.

Eleweke, C.J. \& Rodda, M. (2002). The challenge of enhancing inclusive education in developing countries. International Journal of Inclusive Education, 6(2), 113-126. DOI: 10.1080/13603110110067190

Florian, L., Black-Hawkins, K. \& Rouse, M. (2017). Achievement and inclusion in schools ( $2^{\text {nd }}$ ed.). London: Routledge.

Forlin, C., \& Chambers, D. (2011). Teacher preparation for inclusive education: Increasing knowledge but raising concerns. Asia-Pacific Journal of Teacher Education, 39(1), 17-32.

Fullan, M. (2007). The new meaning of educational change ( $4^{\text {th }}$ ed.). New York: Teachers College Press.

Graham, L. \& Scott, W. (2016). Teacher preparation for inclusive education: Initial teacher education and in-service professional development. Report prepared for the Victorian Department of Education and Training. Retrieved from: https://www.deafeducation.vic.edu.au/Documents/NewsEvents/LitRevIncTe.pdf

Grimes, P. (2010). A quality education for all. A history of the Lao PDR Inclusive Education Project, 1993-2009. Report written for Save the Children Norway. Retrieved from:

https://www.eenet.org.uk/resources/docs/A_Quality_Education_For_All_LaoPDR.pdf

Hehir, T., Grindal, T., Freeman, B., Lamoreau, R., Borquaye, Y. \& Burke, S. (2017). A summary of the evidence on inclusive education. Report prepared for Instituto Alana, in partnership with ABT Associates. Retrieved from: https://alana.org.br/wpcontent/uploads/2016/12/A_Summary_of_the_evidence_on_inclusive_education.pdf

Heymann, J., Stein, M.A. \& Moreno, G. (2014). Disability, employment, and inclusion worldwide. In J. Heymann, M.A.Stein \& G. Moreno (Eds.), Disability and equity at work (pp. 1-19). Oxford, UK: Oxford University Press.

Johnstone, C.J. \& Chapman, D.W. (2009). Contributions and constraints to the implementation of inclusive education in Lesotho. International Journal of Disability, Development, and Education, 56(2), 131-148. DOI: 10.1080/10349120902868582

Jordan, A. \& McGhie-Richmond, D. (2014). Identifying effective teaching practices in inclusive classrooms. In C. Forlin \& T. Loreman (Eds.), Measuring Inclusive Education (pp. 133-162). Bingley, UK: Emerald.

Kuroda, K., Kartika, D. \& Kitamura, Y. (2017). Implications for teacher training and support for inclusive education in Cambodia: An empirical case study in a developing country. JICA Research Institute Working Paper 148. Retrieved from:

https://www.jica.go.jp/jica-ri/publication/workingpaper/wp_148.html

Loreman, T., Forlin, C. \& Sharma, U. (2014). Measuring indicators of inclusive education: A systematic review of the literature. In C. Forlin \& T. Loreman (Eds.), Measuring Inclusive Education (pp. 3-17). Bingley, UK: Emerald.

Messiou, K. (2017) Research in the field of inclusive education: Time for a rethink? International Journal of Inclusive Education, 21(2),146-159. DOI: 10.1080/13603116.2016.1223184

Mittler, P. (2000). Working towards inclusive education: Social contexts. London: Routledge.

Nelson, L.L. (2014). Design and deliver: Planning and teaching using Universal Design for Learning. Baltimore: Brookes.

Nolet, V. \& McLaughlin, M.J. (2005). Accessing the general curriculum: Including students with disabilities in standards-based reform $\left(2^{\text {nd }}\right.$ ed.). Thousand Oaks, CA: Corwin Press. 
Opertti, R., Walker, Z. \& Zhang, Y. (2014). Inclusive education: From targeting groups and schools to achieving quality education as the core of EFA. In L. Florian, The SAGE Handbook of Special Education (pp. 149-169). London: SAGE.

Peters, S.J. (2003). Inclusive education: Achieving Education for All by including those with disabilities and special education needs. Washington, DC: The World Bank.

Phasha, N., Mahlo, D. \& Dei, G.J.S. (Eds.) (2017). Inclusive education in Africa: A critical reader. Rotterdam: Sense.

Rhim, L.M. \& Lancet, S. (2018). How personalized learning models can meet the needs of students with disabilities: Thrive Public Schools case study. Report written for Center on Reinventing Public Education. Retrieved from:

https://www.crpe.org/publications/personalized-learning-models-meet-needs-students-disabilities-thrive-case-study

Rieser, R. (2012). Implementing inclusive education: A Commonwealth guide to implementing Article 24 of the UN Convention on the Rights of Persons with Disabilities ( $2^{\text {nd }}$ ed.). London: Commonwealth Secretariat.

Rose, R. (Ed.) (2010). Confronting obstacles to inclusion: International responses to developing inclusive education. London: Routledge.

Rose, R. \& Doveston, M. (2015). Collaboration across cultures: Planning and delivering professional development for inclusive education in India. Support for Learning, 30(3), 177-191. DOI: 10.1111/1467-9604.12089

Sailor, W. (2015). Advances in schoolwide inclusive school reform. Remedial and Special Education, 36(2), 94-99. DOI: 10.1177/0741932514555021

Save the Children (2016). Inclusive education: What, why, and how - A handbook for program implementers. London: Save the Children. Retrieved from: http://www.eenet.org.uk/resources/docs/SC_2016_inclusive_education_handbook_lowres.pdf

Save the Children \& EENET (2018). The foundations of teaching: Training for educators in core teaching competencies. Retrieved from: https://foundationsofteaching.miraheze.org/wiki/The_Foundations_of_Teaching

Sæbønes, A-M., Bieler, R.B., Baboo, N., Banham, L., Singal, N., Howgego, C., McClain-Nhalpo, C.V., Riis-Hansen, T.C. \& Dansie, G.A. (2015). Towards a disability inclusive education: Background paper for the Oslo Summit on Education for Development. Retrieved from: http://unesdoc.unesco.org/images/0023/002338/233897e.pdf

Schuelka, M.J. (2017). Learning at the top of the world: Education policy construction and meaning in Bhutan. In T.D. Jules \& P. Ressler (Eds.), Re-reading educational policy and practice in small and micro states (pp. 217-236). Bern: Peter Lang.

Schuelka, M.J. (2018). The cultural production of the 'disabled' person: Constructing student difference in Bhutanese schools. Anthropology and Education Quarterly, 49(2), 183-200.

Schuelka, M.J, \& Johnstone, C.J. (2012). Global trends in meeting the educational rights of children with disabilities: From international institutions to local responses. Reconsidering Development, 2(2). Retrieved from https://pubs.lib.umn.edu/index.php/reconsidering/article/view/573

Schuelka, M.J., Sherab, K. \& Nidup, T.Y. (2018). Gross National Happiness, British Values, and non-cognitive skills: Teachers and curriculum in Bhutan and England. Educational Review. DOI: 10.1080/00131911.2018.1474175

Sharma, U., Simi, J., \& Forlin, C. (2015). Preparedness of Pre-service Teachers for Inclusive Education in the Solomon Islands. Australian Journal of Teacher Education, 40(5), 103-116. http://ro.ecu.edu.au/ajte/vol40/iss5/6

Sherab, K., Dorji, K., Dukpa, D., Lhamo, K., Thapa, R. \& Tshomo, S. (2015). Opportunities and challenges of implementing inclusive education in Bhutanese schools: A case study. Report prepared for UNICEF-Bhutan. Thimphu: UNICEF-Bhutan.

Shogren, K.A., McCart, A.B., Lyon, K.J. \& Sailor, W.S. (2015). All means all: Building knowledge for inclusive schoolwide transformation. Research and Practice for Persons with Severe Disabilities, 40(3), 173-191. DOI: 10.1177/1540796915586191

Singal, N. (2006). Inclusive Education in India: International concept, national interpretation. International Journal of Disability, Development, and Education, 53(3), 351-369. DOI: 10.1080/10349120600847797

Singal, N. (2009). Inclusion in the real world: Practitioners making sense of inclusive education in Indian classrooms. In M. Alur \& V. Timmons (Eds.), Inclusive education across cultures: Crossing boundaries, sharing ideas (pp. 210-219). Los Angeles: SAGE.

Sprunt, B., Hoq, H., Sharma, U. \& Marella, M. (2017). Validating the UNICEF/Washington Group Child Functioning Module for Fijian schools to identify seeing, hearing and walking difficulties. Disability and Rehabilitation, 20, 1-11. DOI: 10.1080/09638288.2017.1378929

Srivastava, M., de Boer, A. \& Pijl, S.J. (2015). Inclusive education in developing countries: A closer look at its implementation in the last 10 years. Educational Review, 67(2), 179-19. DOI: 10.1080/00131911.2013.847061

Subban, P. \& Mahlo, D. (2017). 'My attitude, my responsibility': Investigating the attitudes and intentions of pre-service teachers toward inclusive education between teacher preparation cohorts in Melbourne and Pretoria. International Journal of Inclusive Education, 21(4), 441-461. DOI: 10.1080/13603116.2016.1197322

SWIFT (2018). Education center. Retrieved from: http://www.swiftschools.org

Timmons, V. \& Thompson, S.A. (2017). Voices of inclusion. Retrieved from:

https://ourspace.uregina.ca/bitstream/handle/10294/7770/Voices\%20of\%20Inclusion.pdf?sequence=1 
Umeasiegbu, V.I., Diallo, A. \& Gere, B.O. (2018). Rehabilitation practice, employment, and policy for rural development for people with disabilities in West Africa. In D.A. Harley, N.A. Ysasi, M.L. Bishop \& A.R. Fleming (Eds.), Disability and vocational rehabilitation in rural settings: Challenges to service delivery (pp 297-316). Cham, Switzerland: Springer.

UN (2016). General comment No. 4 - Article 24: Right to inclusive education. CRPD/C/GC/4. Retrieved from: https://www.ohchr.org/en/hrbodies/crpd/pages/gc.aspx

UNESCO (2003). Overcoming exclusion through inclusive approaches to education. Paris: UNESCO. Retrieved from: http://unesdoc.unesco.org/images/0013/001347/134785e.pdf

UNESCO (2017). A guide for ensuring inclusion and equity in education. Paris: UNESCO. Retrieved from: http://unesdoc.unesco.org/images/0024/002482/248254e.pdf

UNESCO-IBE (2016). Reaching out to all learners: A resource pack for supporting inclusive education. Geneva: UNESCOIBE. Retrieved from: http://unesdoc.unesco.org/images/0024/002432/243279e.pdf

UNICEF (2015). The investment case for education and equity. New York: UNICEF. Retrieved from: https://www.unicef.org/publications/index_78727.html

UNICEF (2016a). Guide for including disability in education management information systems. New York: UNICEF. Retrieved from: https://www.openemis.org/wp-

content/uploads/2018/04/UNICEF_Guide_for_Including_Disability_in_Education_Management_Information_Systems_2016_en .pdf

UNICEF (2016b). Module on Child Functioning. New York: UNICEF. Retrieved from: https://data.unicef.org/resources/modulechild-functioning/

Villa, R.A. \& Thousand, J.S. (2016). Leading an inclusive school: Access and success for ALL students. Alexandria, VA: ASCD.

World Bank (2017). Disability-inclusive Education in Africa Trust Fund. Retrieved from:

https://www.worldbank.org/en/topic/disability/brief/disability-inclusive-education-in-africa-trust-fund

\section{Suggested citation}

Schuelka, M.J. (2018). Implementing inclusive education. K4D Helpdesk Report. Brighton, UK: Institute of Development Studies.

\section{Suggested Resources and Toolkits}

The following is a listing of some of the key resources and toolkits as mentioned in the above literature synthesis. They are free to access and download.

- Reaching out to all learners: A resource pack for supporting inclusive education. (UNESCO-IBE, 2016), http://unesdoc.unesco.org/images/0024/002432/243279e.pdf

- A guide for ensuring inclusion and equity in education (UNESCO, 2017), http://unesdoc.unesco.org/images/0024/002482/248254e.pdf

- Inclusive education: What, why, and how - A handbook for program implementers. (Save the Children, 2016), http://www.eenet.org.uk/resources/docs/SC_2016_inclusive_education_handbook_lowre s.pdf

- A quality education for all. A history of the Lao PDR Inclusive Education Project, 1993-2009 (Grimes, 2010), https://www.eenet.org.uk/resources/docs/A_Quality_Education_For_All_LaoPDR.pdf

- The foundations of teaching: Training for educators in core teaching competencies (Save the Children \& EENET, 2018), https://foundationsofteaching.miraheze.org/wiki/The_Foundations_of_Teaching

- Implementing Inclusive Education (Rieser, 2012), https://tinyurl.com/yc4f6jyz

- Key principles for promoting quality in inclusive education (EASNIE, 2011), https://www.european-agency.org/sites/default/files/key-principles-for-promoting-qualityin-inclusive-education-recommendations-for-practice_Key-Principles-2011-EN.pdf

- Index for Inclusion, http://www.indexforinclusion.org

- Swift Education Center, http://www.swiftschools.org 


\section{About this report}

This report is based on five days of desk-based research. The K4D research helpdesk provides rapid syntheses of a selection of recent relevant literature and international expert thinking in response to specific questions relating to international development. For any enquiries, contact helpdesk@k4d.info.

K4D services are provided by a consortium of leading organisations working in international development, led by the Institute of Development Studies (IDS), with Education Development Trust, Itad, University of Leeds Nuffield Centre for International Health and Development, Liverpool School of Tropical Medicine (LSTM), University of Birmingham International Development Department (IDD) and the University of Manchester Humanitarian and Conflict Response Institute (HCRI).

This report was prepared for the UK Government's Department for International Development (DFID) and its partners in support of pro-poor programmes. It is licensed for non-commercial purposes only. K4D cannot be held responsible for errors or any consequences arising from the use of information contained in this report. Any views and opinions expressed do not necessarily reflect those of DFID, K4D or any other contributing organisation. (C) DFID - Crown copyright 2018.

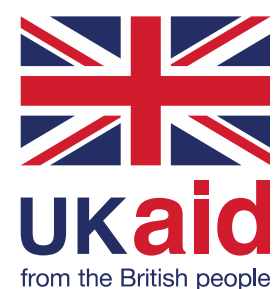

